Tatsuo Kono • Takuo Migita $\cdot$ Satomi Koyama Ichiro Seki

\title{
Another observation of microphthalmia in an XX male: microphthalmia with linear skin defects syndrome without linear skin lesions
}

\begin{abstract}
A case of microphthalmia with Xp microdeletion is reported. The patient was a boy who showed bilateral microphthalmia with corneal opacities, hypospadias without evidence of hypogonadism, and a conduction disturbance of the heart (Wenckebach conduction). No skin lesion was discerned. High-resolution chromosome analysis revealed the karyotype of $46, \mathrm{X}, \operatorname{del}(\mathrm{X})(\mathrm{p} 22)$. The phenotype was considered to be microphthalmia with linear skin defects (MLS) syndrome without skin lesions. Polymerase chain reaction and fluorescence in-situ hybridization analyses revealed that the chromosome aberration resulted from an $\mathrm{X} ; \mathrm{Y}$ translocation: the presence of pseudoautosomal boundary $\mathrm{Y}$ and the sex-determining region of $\mathrm{Y}$ was confirmed, while $\mathrm{Xp}$ deletion involving the region distal to DXS1129 was ascertained. Thus the chromosome designation using the ISCN 1995 nomenclature is $46, X, \operatorname{der}(X), t(X ; Y)(p 22.13 ; q 11.2)$. Despite the absence of skin lesions, the Xp deletion of our patient corresponded to those of previously reported typical cases of MLS syndrome. Our observation further supports the current hypothesis that the phenotypic variation of MLS syndrome represents tissue-different $\mathrm{X}$ inactivation rather than different genetic effects of two contiguous genes.
\end{abstract}

Key words Microphthalmia with linear skin defects syndrome $($ MLS $) \cdot X$ inactivation $\cdot \mathrm{Xp}$ microdeletion $\cdot \mathrm{XX}$ male - Atrioventricular block

\section{T. Kono $(\square)$}

Department of Radiology, Dokkyo University School of Medicine, 880 Kita-kobayashi, Mibu-machi, Shimotsuga-gun, Tochigi 321-0293, Japan

Tel. +81-282-87-2171; Fax +81-282-86-4940

e-mail: t-kono@dokkyomed.ac.jp

T. Kono $\cdot$ T. Migita $\cdot$ S. Koyama $\cdot$ I. Seki

Department of Pediatrics, Tokyo Metropolitan Bokuto General

Hospital, Tokyo, Japan

\section{Introduction}

Microphthalmia with linear skin defects (MLS) syndrome (MIN 309801; McKusick et al. 1994) is a rare congenital malformation syndrome that results from microdeletions of $\mathrm{Xp22.3.} \mathrm{Most} \mathrm{affected} \mathrm{individuals} \mathrm{are} \mathrm{females} \mathrm{and} \mathrm{affected}$ males are $\mathrm{XX}$ males with a karyotype of $46, \mathrm{X}, \operatorname{der}(\mathrm{X}) \mathrm{t}(\mathrm{X} ; \mathrm{Y})$ (Al-Gazali et al. 1990; Stratton et al. 1998). The clinical manifestations include microphthalmia and hypoplastic skin lesions on the head, face, and neck. Heart defects, short stature, anal anomalies, and mental retardation are occasional features. The phenotypic variations are significant and some patients possess only one of the two major anomalies. To date, 22 affected individuals have been reported (Ropers et al. 1982; Al-Gazali et al. 1988; 1990; Donnenfeld et al. 1990; Temple et al. 1990; Allanson and Richter 1991; Gericke et al. 1991; Thies et al. 1991; Lindor et al. 1992; Naritomi et al. 1992; Happle et al. 1993; Schaefer et al. 1993; 1996; Bird et al. 1994; Eng et al. 1994; Lindsay et al. 1994; Mucke et al. 1995; Stratton et al. 1998).

Cytogenetic studies of MLS syndrome have revealed a variety of sexchromosome aberrations, including del Xp22 (-pter) in 11 female patients, translocation between the $\mathrm{X}$ and an autosomal chromosome in five female patients, $\mathrm{X} ; \mathrm{Y}$ translocation in four female patients, 46,XX in two female patients, of whom one did not undergo high-resolution analysis (Happle et al. 1993) and the other with a normal karyotype who did (Bird et al. 1994), as well as two XX male patients. Recent molecular investigations of Xp microdeletions in MLS syndrome have detailed the critical region of the genetic map (Schaefer et al. 1993; 1996).

Here, we report a boy who had the karyotype of 46 , $\mathrm{X}, \operatorname{der}(\mathrm{X}) \mathrm{t}(\mathrm{X} ; \mathrm{Y})$ and microphthalmia, but not skin lesions. The $\mathrm{Xp}$ microdeletion was clarified with polymerase chain reaction (PCR) and fluorescence in-situ hybridization (FISH) techniques. The relation of the extension of the Xp microdeletion in MLS syndrome with its phenotypic variations is discussed. 


\section{Case report}

A newborn infant was referred because of microphthalmia and hypospadias. The patient was the second child of healthy unrelated parents, a 31-year-old father and a 31year old mother, and was born at full term after an unremarkable pregnancy and delivery. Birth weight was $3056 \mathrm{~g}$, length $50 \mathrm{~cm}$, and head circumference $33 \mathrm{~cm}$. The family history was not noteworthy, other than the fact that the mother previously experienced a spontaneous abortion. The older brother of the patient was healthy. On physical examination, the gender phenotype of the patient was male with hypospadias. Both testes were found in the scrotum and measured $12 \mathrm{~mm}$ (right) and $6 \mathrm{~mm}$ (left) in maximum length. The penis measured $3 \mathrm{~cm}(-0.7 \mathrm{SD})$ in stretched length. No skin abnormalities were evident. Neurologic assessment yielded normal findings. Cardiac evaluation revealed second-degree atrioventricular block (Wenckebach conduction) without cardiac anomalies. Ophthalmologic examination showed bilateral microphthalmia and corneal opacities (Fig. 1a). No evidence of coloboma or retinal lacuna was noted. Routine hematological and biochemical tests were normal. Endocrinological examinations did not show evidence of hypogonadism. Abdominal ultrasound, magnetic resonance imaging (MRI), intravenous

Fig. 1 a Microphthalmia and corneal opacity (right eye). b Computed tomography of the orbit
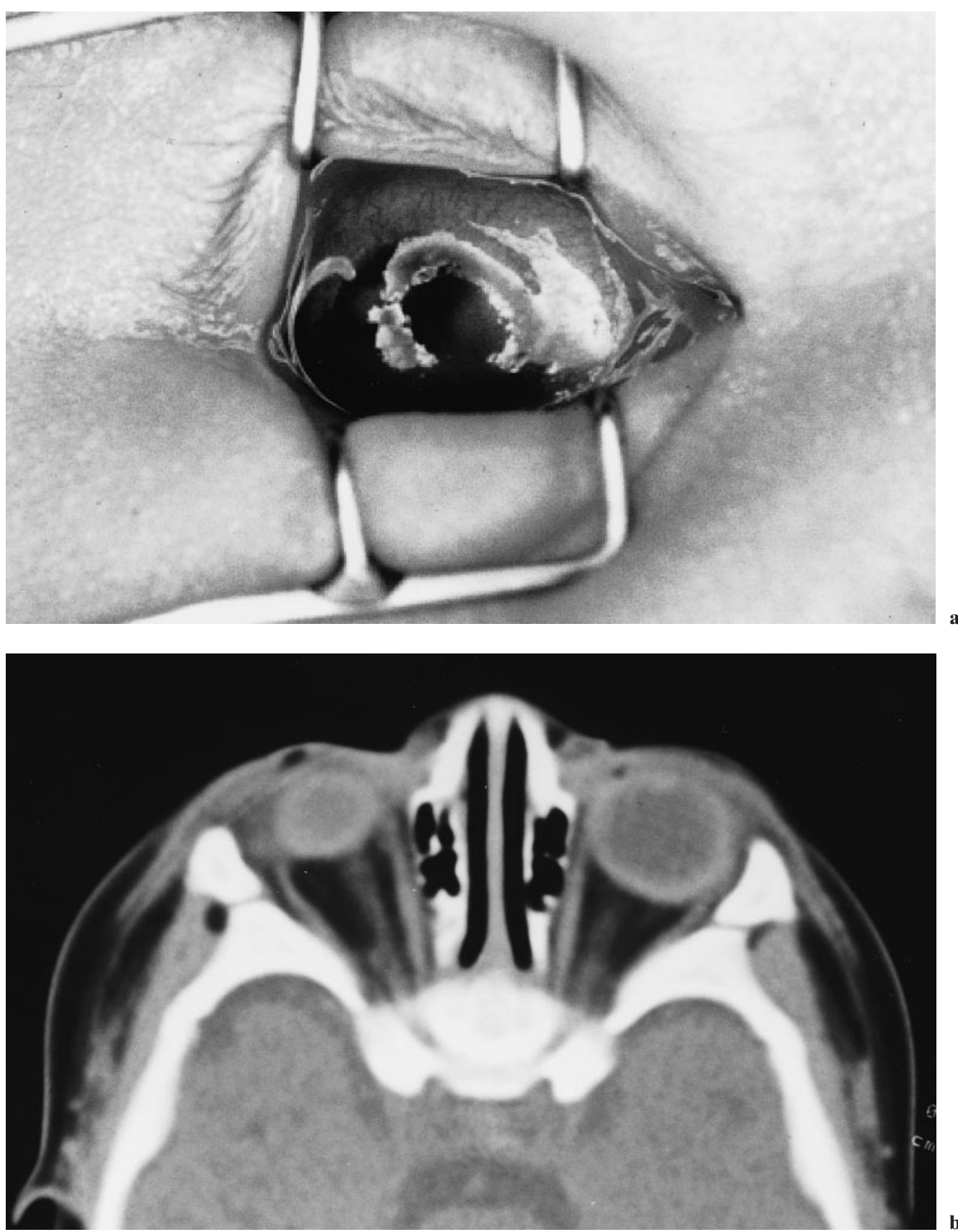
urography, and retrograde urography demonstrated a normal male genitourinary system. Computed tomography (CT) of the brain and a skeletal survey showed normal findings. CT of the orbit revealed bilateral microphthalmia with an intact optic nerve sheath and retrobulbar space (Fig. 1b). The right bulbar diameter was $11 \mathrm{~mm}$ and the left was $15 \mathrm{~mm}$. The ophthalmologic examination of the mother was essentially normal except for myopia. Chromosomes were analyzed by $\mathrm{G}$ banding, $\mathrm{Q}$ banding, and highresolution techniques, and the karyotype was designated as 46,X,del(X)(p22) (Fig. 2). The results of Y-specific boundary sequences assayed by PCR and Xp sequences assayed by FISH are summarized in Table 1. DNA was obtained from the patient's venous blood samples. DNA probes of known regional location were provided by other investigators. Band intensity was measured and compared with the intensity control. Pseudoautosomal boundary Y (PABY) and the sex-determining region of Y (SRY) were detected, while AMGL (a centromere region) and the Yq loci were not. FISH analysis revealed deletions distal to DXS1129. Thus the chromosome designation using the ISCN 1995 nomenclature is $46, \mathrm{X}, \operatorname{der}(\mathrm{X}), \mathrm{t}(\mathrm{X} ; \mathrm{Y})(\mathrm{p} 22.13 ; \mathrm{q} 11.2)$. Chromosomal analyses of the parents and older brother revealed normal karyotypes.

\section{Discussion}

The gender manifestations of the present patient corresponded to those of previously reported XX males with SRY (Magenis et al. 1982; 1987; Mittwoch 1992), whereas the combination of Xp microdeletion with ophthalmologic manifestations in our patient attracted a diagnosis of MLS syndrome despite the absence of linear skin defects. Until now, two XX males with MLS syndrome have been reported (Al-Gazali et al. 1990; Stratton et al. 1998), and, unlike our patient, both patients exhibited ocular and skin abnormalities characteristic of MLS syndrome. Consequently, the presence of SRY does not modify the phenotype of MLS syndrome.

Table 1 Summary of the genetic analysis of DNA markers

\begin{tabular}{|c|c|c|c|c|c|}
\hline \multicolumn{6}{|l|}{ Xp sequences } \\
\hline Locus & DXS410 & AMG & DXS1129 & DXF22S4 & DXS16 \\
\hline Result & - & - & + & + & + \\
\hline \multicolumn{6}{|l|}{ Yp sequences } \\
\hline Locus & PABY & SRY & AMGL & DYZ3 & DYS139 \\
\hline Result & + & + & - & - & - \\
\hline
\end{tabular}

Fig. $2 \mathrm{Xp}$ microdeletion was detected using highresolution techniques and the karyotype was designated as 46,X,del $(X)(\mathrm{p} 22)$

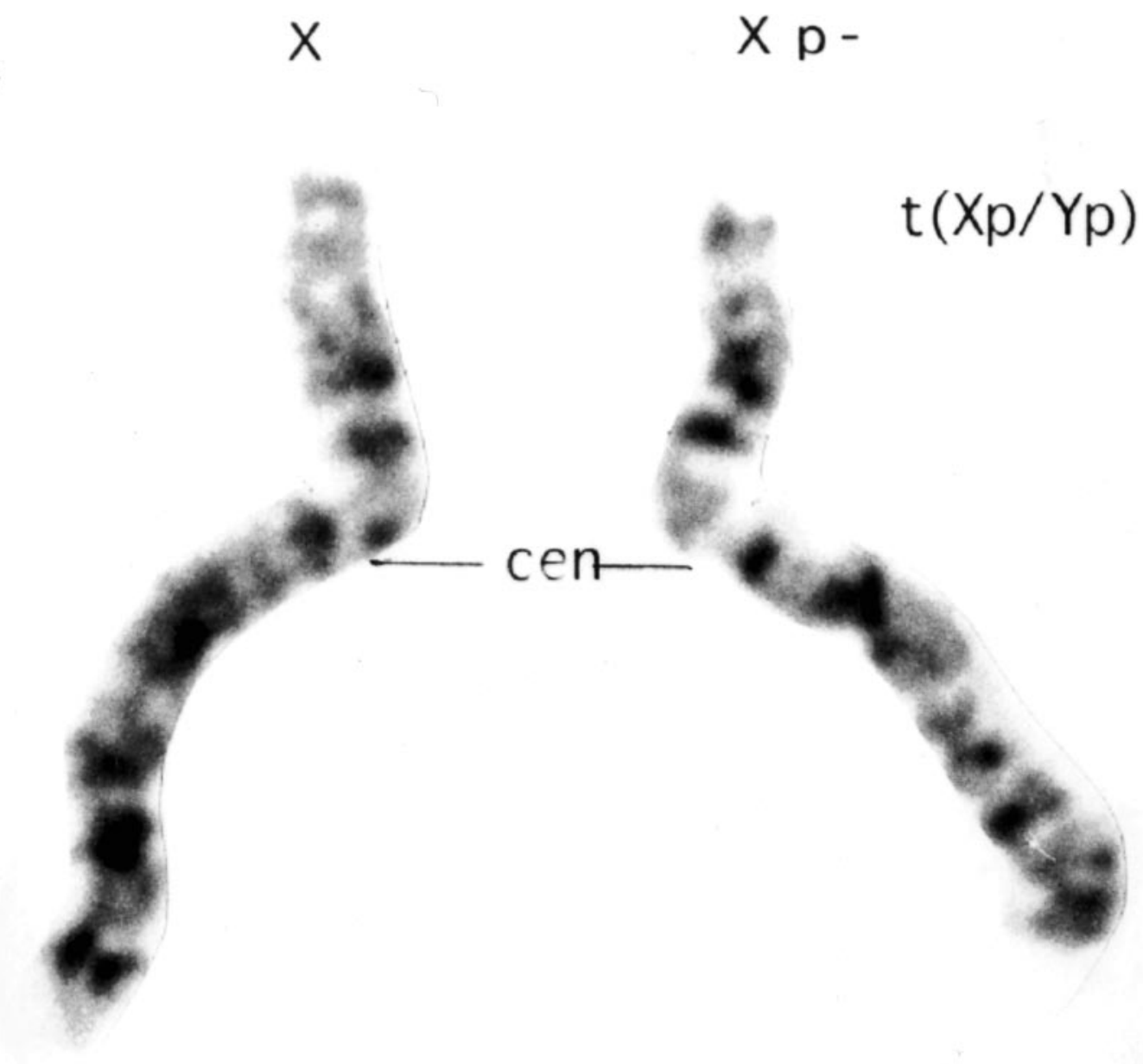




\begin{tabular}{|c|c|c|c|c|c|c|}
\hline & Karyotype & Sex & Ocular findings & Dermatologic findings & Heart findings & Reference \\
\hline \multicolumn{7}{|c|}{ (A) Reported cases with both microphthalmia and skin defect } \\
\hline 1 & $\begin{array}{l}46, X, \operatorname{der}(X) \\
t(X ; Y)\end{array}$ & $\mathrm{M}$ & microphthalmia $(\mathrm{L}, \mathrm{R})$ & $\begin{array}{l}\text { linear hypoplasia over neck } \\
\text { and face }\end{array}$ & ND & $\begin{array}{l}\text { Al-Gazali et al. } \\
(1988,1990)\end{array}$ \\
\hline 2 & $\begin{array}{l}46, X, \operatorname{der}(\mathrm{X}) \\
\mathrm{t}(\mathrm{X} ; \mathrm{Y}) \\
(\mathrm{p} 22.3 ; \mathrm{q} 11.2)\end{array}$ & $\mathrm{F}$ & $\begin{array}{l}\text { microphthalmia }(\mathrm{L}, \mathrm{R}) \\
\text { corneal opacity }(\mathrm{L}) \\
\text { corneal perforation }(\mathrm{R})\end{array}$ & linear defect & ND & $\begin{array}{l}\text { Al-Gazali et al. } \\
\text { (1988) }\end{array}$ \\
\hline 3 & $\begin{array}{l}\text { 46,X,der(X) } \\
\text { t(X;Y) } \\
\text { (p22.3; } 11.2)\end{array}$ & $\mathrm{F}$ & $\begin{array}{l}\text { microphthalmia } \\
\text { orbital cyst }\end{array}$ & $\begin{array}{l}\text { linear defects one face, neck, } \\
\text { shoulders, and chest }\end{array}$ & ND & $\begin{array}{l}\text { Al-Gazali et al. } \\
\text { (1988) }\end{array}$ \\
\hline 4 & $\begin{array}{l}46, X, \operatorname{del}(\mathrm{X}) \\
(\mathrm{p} 22.31)\end{array}$ & $\mathrm{F}$ & microphthalmia $(\mathrm{L}, \mathrm{R})$ & $\begin{array}{l}\text { patchy cutis aplasia on face, } \\
\text { neck, and extremities }\end{array}$ & ND & $\begin{array}{l}\text { Friedman et al. } \\
\text { (1988) }\end{array}$ \\
\hline 5 & $\begin{array}{l}46, \mathrm{X}, \mathrm{del}(\mathrm{X}) \\
(\mathrm{p} 22.2)\end{array}$ & $\mathrm{F}$ & $\begin{array}{l}\text { microphthalmia (L) } \\
\text { sclerocornea (L,R) }\end{array}$ & $\begin{array}{l}\text { raw linear lesions on face } \\
\text { and neck }\end{array}$ & ND & Temple et al. (1990) \\
\hline 6 & $\begin{array}{l}46, X, \operatorname{del}(\mathrm{X}) \\
(\mathrm{p} 22.2)\end{array}$ & $\mathrm{F}$ & $\begin{array}{l}\text { microphthalmia }(\mathrm{L}, \mathrm{R}) \\
\text { corneal opacities }\end{array}$ & $\begin{array}{l}\text { hypoplastic erythematous } \\
\text { areas on head and neck }\end{array}$ & ND & $\begin{array}{l}\text { Allanson and Richter } \\
\text { (1991) }\end{array}$ \\
\hline 7 & $\begin{array}{l}46, X, \operatorname{del}(X) \\
\mathrm{t}(2 ; \mathrm{X}) \\
(\mathrm{p} 25.1 ; \mathrm{p} 22.1)\end{array}$ & $\mathrm{F}$ & $\begin{array}{l}\text { microphthalmia } \\
\text { sclerocornea }(\mathrm{L}, \mathrm{R})\end{array}$ & $\begin{array}{l}\text { linear skin lesions on face } \\
\text { and neck }\end{array}$ & ND & Gericke et al. (1991) \\
\hline 8 & $\begin{array}{l}46, X, \operatorname{der}(X) \\
\text { t(2;X) } \\
(\mathrm{p} 25.1 ; \mathrm{p} 22.1)\end{array}$ & $\mathrm{F}$ & $\begin{array}{l}\text { microphthalmia } \\
\text { sclerocornea }(\mathrm{L}, \mathrm{R})\end{array}$ & $\begin{array}{l}\text { linear skin lesions on face } \\
\text { and neck }\end{array}$ & ND & Gericke et al. (1991) \\
\hline 9 & $\begin{array}{l}\text { 46,X,del(X) } \\
(\mathrm{p} 22.3)\end{array}$ & $\mathrm{F}$ & $\begin{array}{l}\text { microphthalmia }(\mathrm{R}) \\
\text { corneal clouding }(\mathrm{L}, \mathrm{R}) \\
\text { iris coloboma }(\mathrm{R}) \\
\text { embryotoxon }(\mathrm{L}) \\
\text { chorioretinopathy }\end{array}$ & $\begin{array}{l}\text { linear desquamative } \\
\text { eruption on face and neck } \\
\text { depigmentated lesions on } \\
\text { trunk }\end{array}$ & ND & $\begin{array}{l}\text { Naritomi et al. } \\
\text { (1992) }\end{array}$ \\
\hline 10 & $\begin{array}{l}\text { 46,X,del(X) } \\
(\mathrm{p} 22.1 \mathrm{p} 22.31)\end{array}$ & $\mathrm{F}$ & $\begin{array}{l}\text { microphthalmia }(\mathrm{L}, \mathrm{R}) \\
\text { corneal clouding }(\mathrm{L}, \mathrm{R})\end{array}$ & $\begin{array}{l}\text { linear hypoplasia with } \\
\text { telangiectasia on face } \\
\text { and neck } \\
\text { hypopigmented patches on } \\
\text { trunk }\end{array}$ & AV block (Mobitz II) & $\begin{array}{l}\text { Naritomi et al. } \\
\text { (1992) }\end{array}$ \\
\hline 11 & $\begin{array}{l}46, X, \operatorname{der}(\mathrm{X}) \\
\mathrm{t}(\mathrm{X} ; ?) \\
(\mathrm{p} 22.3 ; ?)\end{array}$ & $\mathrm{F}$ & $\begin{array}{l}\text { microphthalmia }(\mathrm{L}, \mathrm{R}) \\
\text { sclerocornea } \\
\text { dense cataract }\end{array}$ & $\begin{array}{r}\text { reticulolinear nonvesicular } \\
\text { lesions on face and neck }\end{array}$ & $\begin{array}{l}\text { VSD, ASD } \\
\text { overriding aorta } \\
\text { azygos continuation } \\
\text { junctional rhythm } \\
\text { wandering pacemaker }\end{array}$ & Lindor et al. (1992) \\
\hline 12 & $\begin{array}{l}\text { 46,X,del }(\mathrm{X}) \\
(\mathrm{p} 22.1)\end{array}$ & $\mathrm{F}$ & $\begin{array}{l}\text { microphthalmia }(\mathrm{L}, \mathrm{R}) \\
\text { corneal opacity }(\mathrm{L}, \mathrm{R}) \\
\text { glaucoma }(\mathrm{L}, \mathrm{R}) \\
\text { retinal detachment }(\mathrm{L}, \mathrm{R})\end{array}$ & linear lesions on face & patent foramen ovale & $\begin{array}{l}\text { Lebel et al. (1992) } \\
\text { Eng et al. (1994) }\end{array}$ \\
\hline 13 & $\begin{array}{l}46, \mathrm{XX} \\
\text { (not high resolution) }\end{array}$ & $\mathrm{F}$ & $\begin{array}{l}\text { microphthalmia }(\mathrm{L}, \mathrm{R}) \\
\text { blepharophimosis }\end{array}$ & $\begin{array}{l}\text { linear erythematous lesion } \\
\text { on right cheek and neck }\end{array}$ & $\begin{array}{l}\text { cardiomyopathy } \\
\text { ventricular fibrillation }\end{array}$ & Happle et al. (1993) \\
\hline 14 & $\begin{array}{l}46, \mathrm{X}, \mathrm{del}(\mathrm{X}) \\
(\mathrm{p} 22.2)\end{array}$ & $\mathrm{F}$ & $\begin{array}{l}\text { microphthalmia }(\mathrm{L}, \mathrm{R}) \\
\text { cloudy cornea }(\mathrm{L}, \mathrm{R})\end{array}$ & $\begin{array}{l}\text { reticulolinear scar-like } \\
\text { lesions on face }\end{array}$ & ND & Lindsay et al. (1994) \\
\hline 15 & $\begin{array}{l}\text { 46,X,del }(\mathrm{X}) \\
(\mathrm{p} 22.2)\end{array}$ & $\mathrm{F}$ & $(+)$ & $(+)$ & $?$ & $\begin{array}{l}\text { Magenis } \\
\text { (Schaefer's pers. } \\
\text { commun.) }\end{array}$ \\
\hline 16 & $\begin{array}{l}46, X, \operatorname{der}(\mathrm{X}) \\
\mathrm{t}(\mathrm{X} ; \mathrm{Y})\end{array}$ & M & microphthalmia & linear skin streaks & secundum ASD & Stratton et al. (1998) \\
\hline \multicolumn{7}{|c|}{ (B) Reported cases with only microphthalmia (no skin defect) } \\
\hline 1 & $\begin{array}{l}46, X, \operatorname{der}(X) \\
\mathrm{t}(\mathrm{X} ; 3) \\
(\mathrm{p} 22.2 ; \mathrm{q} 12)\end{array}$ & $\mathrm{F}$ & microphthalmia & No skin lesion & ND & Ropers et al. (1982) \\
\hline 2 & $\begin{array}{l}46, X, \operatorname{der}(\mathrm{X}) \\
\mathrm{t}(\mathrm{X} ; 3) \\
(\mathrm{p} 22.2 ; \mathrm{p} 22.2)\end{array}$ & $\mathrm{F}$ & $\begin{array}{l}\text { microphthalmia }(\mathrm{R}) \\
\text { sclerocornea }(\mathrm{R}) \\
\text { defects in retinal } \\
\text { pigment epithelium }\end{array}$ & No skin lesion & normal & $\begin{array}{l}\text { Donnenfeld et al. } \\
\text { (1990) }\end{array}$ \\
\hline 3 & $\begin{array}{l}46, X, \operatorname{del}(\mathrm{X}) \\
(\mathrm{p} 22.3)\end{array}$ & $\mathrm{F}$ & $\begin{array}{l}\text { microphthalmia } \\
\text { iridoschisis }\end{array}$ & No skin lesion & ND & Thies et al. (1991) \\
\hline 4 & $\begin{array}{l}46, X, \operatorname{der}(\mathrm{X}) \\
\mathrm{t}(\mathrm{X} ; \mathrm{Y}) \\
(\mathrm{p} 22.13 ; \mathrm{p} 11.2)\end{array}$ & M & microphthalmia & No skin lesion & $\begin{array}{l}\text { AV block } \\
\text { (Wenckebach) }\end{array}$ & $\begin{array}{l}\text { Koyama et al. (1993) } \\
\text { Present case (1998) }\end{array}$ \\
\hline \multicolumn{7}{|c|}{ (C) Reported cases with only skin defect (no microphthalmia) } \\
\hline 1 & $\begin{array}{l}46, \mathrm{X}, \operatorname{del}(\mathrm{X}) \\
(\mathrm{p} 22.2)\end{array}$ & $\mathrm{F}$ & ND (fetus) & wide skin defect & ND & Lindsay et al. (1994) \\
\hline 2 & $46, \mathrm{XX}$ & $\mathrm{F}$ & No microphthalmia & $\begin{array}{l}\text { erythematous depressed } \\
\text { lesions on face and neck }\end{array}$ & $\begin{array}{l}\text { ASD } \\
\text { WPW syndrome } \\
\text { oncotic cardiomyopathy }\end{array}$ & Bird et al. (1994) \\
\hline 3 & $\begin{array}{l}\text { 46,X,del }(\mathrm{X}) \\
(\mathrm{p} 22.2)\end{array}$ & $\mathrm{F}$ & No microphthalmia & $(+)$ & ? & $\begin{array}{l}\text { Beaudet } \\
\text { (Schaefer's pers. } \\
\text { commun.) }\end{array}$ \\
\hline
\end{tabular}

ND, not documented; AV block, atrioventricular block; VSD, ventricular septal defect; ASD, atrial septal defect; WPW, Wolf-ParkinsonWhite 
Table 3 Breakpoints of reported cases

\begin{tabular}{|c|c|c|c|c|c|c|c|c|c|}
\hline & Case & DXS410 & AMG & DXS1135 & DXS1129 & DXS1144 & DXS22S4 & PRPS2 & DXS16 \\
\hline \multicolumn{10}{|c|}{ Reported cases } \\
\hline$M+S$ & 3 & & - & - & - & - & + & + & + \\
\hline$M+S$ & 5 & - & - & + & + & + & + & + & + \\
\hline$M+S$ & 9 & & - & - & - & - & + & + & + \\
\hline$M+S$ & 15 & - & - & + & + & + & + & + & + \\
\hline $\mathrm{S}$ & 1 & & - & & & - & - & - & + \\
\hline $\mathrm{S}$ & 2 & - & - & - & - & - & + & + & + \\
\hline $\mathrm{S}$ & 3 & & - & & & - & - & - & + \\
\hline \multicolumn{10}{|c|}{ Present case } \\
\hline M & 4 & - & - & & + & & + & & + \\
\hline
\end{tabular}

$\mathrm{M}+\mathrm{S}$, microphthalmia and skin lesions; $\mathrm{M}$, only microphthalmia; $\mathrm{S}$, only skin lesions. Case numbers correspond to those in Table 2

The relationship between the clinical features and the karyotypes of previously reported cases with MLS are summarized in Table $2(\mathrm{~A}-\mathrm{C})$. These cases were divided into three categories, comprising the first group with both microphthalmia and skin lesions (Table 2A), the second group with only microphthalmia (Table $2 \mathrm{~B}$ ), and the third group with only skin lesions (Table 2C). Although there has been debate on whether or not only microphthalmia or skin lesions warrant a diagnosis of MLS syndrome, recent investigations of deletion maps of these three groups have elucidated that the extension of the Xp deletion significantly overlaps among the three groups (Table 3); thus either ocular or skin lesions, along with microdeletion of the Xp critical region, are regarded as sufficient for a diagnosis of MLS syndrome (Wapenaar et al. 1993; Schnur and Wick 1995; Temple and Al-Gazali 1995).

Moreover, it is intriguing that Xp microdeletion is generally larger in the third group than in the first and second groups: the regions distal to DXS1135 are invariably deleted in the first and second groups, whereas more proximal regions are included in the deletion of the third group. This fact imposes some difficulty in accounting for the phenotypic variations among the three groups based on the contiguous gene theory. The hypothesis of tissue-specific X chromosome inactivation with a deletion of a single gene or very closely located genes is more acceptable.

The differential diagnosis of MLS syndrome includes Lenz microphthalmia syndrome (LM), Aicardi syndrome (AS), and focal dermal hypoplasia (FDH) or Goltz syndrome (Wettke-Schafer and Kanther, 1983; Rodini et al. 1992; Shastry, 1993; Paulger et al. 1997). In particular, there has been much debate on whether or not MLS syndrome, AS, and FDH represent variable phenotypes of the same contiguous gene syndrome or the variable consequences of defects of the same gene (Lindsay et al. 1994; Ballabio et al. 1995). Schaefer et al. (1996) showed that the highly conserved human holocytochrome $c$-type synthetase gene is located in the MLS critical region and that the gene is deleted in all cases with MLS, but not in patients with FDH or AS; thus the authors tentatively concluded that AS and FDH are distinctive from MLS syndrome. Further molecular investigations are required to resolve this issue.

It should be emphasized that our patient had Wenckebach conduction. To date, five cases of MLS syndrome with heart diseases (e.g. congenital heart defects, cardiomyopathy, and conduction disturbances) have been reported. These have included intermittent junctional rhythm and wandering atrial pacemaker with congenital heart defects (Lindor et al. 1992), ventricular fibrillation with hypertrophic cardiomyopathy (Happel et al. 1992), Morbitz II atrioventricular block (Naritomi et al. 1992), oncocytic cardiomyopathy with congenital heart defect and Wolf-Parkinson-White syndrome (Bird et al. 1994), and secundum atrial septal defect (Stratton et al. 1998). Schaefer et al. (1996) speculated that the deficiency of human holocytochrome $c$-type synthetase may be related to conduction disturbances in MLS syndrome. Accordingly, patients with MLS syndrome should be scrutinized for potentially hazardous heart problems.

Acknowledgments We are grateful to Dr. Gen Nishimura, Department of Radiology, Dokkyo University School of Medicine for help in preparing the manuscript, and to Professor Yasuo Nakagome, Department of Human Genetics, University of Tokyo, and Dr. Hideki Yagi, Department of Pediatrics, University of Gumma, for their generous support in DNA analyses.

\section{References}

Al-Gazali LI, Mueller RF, Caine A, Dennis NR, Antoniou A, Fitchett M, Insley J, Goodfellow PG, Hulten M (1988) An XX male and two $t(X ; Y)$ females with linear skin defects: and congenital microphthalmia: A new syndrome at Xp22.3. J Med Genet 25: 638639

Al-Gazali LI, MuellerRF, Caine A, Antoniou A, McCartney A, Fitchett M, Dennis NR (1990) Two 46,XX,t(X;Y) females with linear skin defects and congenital microphthalmia: A new syndrome at Xp22.3. J Med Genet 27: 59-63

Allanson J, Richter S (1991) Linear skin defects and congenital microphthalmia: A new syndrome at Xp22.2. J Med Genet 28: 143 144

Ballabio A (1995) MLS, Aicardi and Goltz syndromes: How many genes involved? Am J Med Genet 59: 100

Bird LM, Krous HF, Eichenfield LF, Swalwell CI (1994) Female infant with oncocytic cardiomyopathy and microphthalmia with linear skin defects (MLS): A clue to the pathogenesis of oncocytic cardiomyopathy?. Am J Med Genet 53: 141-148

Donnenfeld AE, Graham Jr JM, Packer RJ, Aquino R, Berg SZ, Emanuel BS (1990) Microphthalmia and chorioretinal lesions in a girl with an Xp22.2-pter deletion and partial 3p trisomy: Clinical observetions relevant to Aicardi syndrome gene localization. Am J Med Genet 37: 182-186

Eng A, Lebel RR, Elejalde BR, Anderson C, Bennett L (1994) Linear skin defects associated with microphthalmia and other malformations, with chromosome deletion Xp22.1. J Am Acad Dermatol 31: 680-682 
Fergunson-Smith MA, Cooke A, Affara NA, Boyd E, Tolmie JL (1990) Genotype-phenotype correlations in XX males and their bearing on current theories of sex determination. Hum Genet 84: 198-202

Friedman PA, Rao KW, Teplin SW, Aylsworth AS (1988) Provisional deletion mapping of the focal dermal hypoplasia (FDH) gene to Xp22.31. Am J Hum Genet 43 (Suppl): A50

Gericke GS, Myburg E, Bester R, Van Rensburg EJ, Neethling E (1991) Further delineation of the Xp22.2-pter syndrome of linear skin lesions, microphthalmia and anterior chamber eye abnormalities. Am J Hum Genet 49 (Suppl): A271

Happle R, Daniels O, Koopman RJJ (1993) MIDAS Syndrome (Microphthalmia, Dermal Aplasia, and Sclerocornea): An X-linked phenotype distinct from Goltz syndrome. Am J Med Genet 47: 710 713

Koyama S, Kono T, Uchida K, Noguchi E, Suzuki K, Yamasuge M, Otsuka M, Ito M, Suzuki M, Migita T, Seki I (1993) XX male with ocular symptoms [Japanese]. Presented at the 34th Annual Meeting of the Japanese Teratology Society at Kochi, Japan. Congenital Anomalies, 34, B-02

Lebel RR, Elejade BR, Bennett L, Eng A, Husayni T, Sugar J, Gibson L, Anderson C (1992) Gazali-Temple syndrome: Dermatologic streaks, microphthalmia and chromosome rearrangements with chromosome breakpoints near Xp22.3. Presented at March of Dimes 24th Clinical Genetics Conference, A37, Stanford, CA

Lindor NM, Michela VV, Hoppe DA, Driscoll DJ, Leavitt JA, Dewald GW (1992) Xp22.3 microdeletion syndrome with microphthalmia, sclerocornea, linear skin defects, and congenital heart defects. Am J Med Genet 44: 61-65

Lindsay EA, Grillo A, Ferrero GB, Roth EJ, Magenis E, Grompe M, Hulten M, Gould C, Baldini A, Zoghbi HY, Ballabio A (1994) Microphthalmia with linear skin defects (MLS) syndrome: Clinical, cytogenetic, and molecular characterization. Am J Med Genet 49: 229-234

Magenis RE, Webb MJ, McKean RS, Tomar D, Allen LJ, Kammer H, Van Dyke DL, Lovrien E (1982) Translocation (X;Y) (p22.33;p11.2) in XX males: Etiology of male phenotype. Hum Genet 62: 271-276

Magenis RE, Casanova M, Fellous M, Olson S, Sheehy R (1987) Further cytologic evidence for Xp-Yp translocation in XX males using in situ hybridization with Y-derived probe. Hum Genet 75: 228-233

McKusick VA, Francomano CA, Antonarakis SE, Pearrson PL (1994) Mendelian inheritence in man, 11th edn. The Johns Hopkins University Press, Baltimore, MD

Mittwoch U (1992) Sex determination and sex reversal: Genotype, phenotype, dogma and semantics. Hum Genet 89: 467-479

Mucke J, Happel R, Theile H (1995) MIDAS syndrome respectively MLS syndrome: A separate entity rather than a particular lyonization pattern of gene causing Goltz syndrome. Am J Med Genet 57: 117-118
Naritomi K, Izumikawa Y, Nagatani S, Fukushima Y, Wakui K, Niikawa N, Hirayama K (1992) Combined Goltz and Aicardi syndromes in a terminal Xp deletion: Are they a contiguous gene syndrome? Am J Med Genet 43: 839-843

Paulger BR, Kraus EW, Pulitzer DR, Moore CM (1997) Xp microdeletion syndrome characterized by pathognomonic linear skin defects on the head and neck. Pediatr Dermatol 14: 26-30

Rodini ESO, Nardi A, Guion-Almeida ML, Richieri-Costa A (1992) Ectodermal dysplasia, ectodactyly, clefting, anophthalmia/ microphthalmia, and genitourinary anomalies: Nosology of GoltzGorlin syndrome versus EC syndrome. Am J Med Genet 42: 276280

Ropers HH, Zuffardi O, Bianchi E, Tiepolo L (1982) Agenesis of the corpus callosum, ocular and skeletal anomalies (X-linked dominant Aicardi syndrome) in a girl with balanced X/3 translocation. Hum Genet 61: 364-368

Schaefer L, Ferrero GB, Grillo A, Bassi MT, Roth EJ, Wapenaar MC, Ommen GJB, Mohandas TK, Rocchi M, Zoghbi HY, Ballabio A (1993) A high resolution deletion map of human chromosome Xp22. Nature Genet 4: 272-279

Schaefer L, Ballabio A, Zoghbi H (1996) Cloning and characterization of a putative human holocytochrome $c$-type synthetase gene (HCCS) isolated from the critical region for microphthalmia with linear skin defects. Genomics 34: 166-172

Schnur RE, Wick PA (1995) Intragenic Taql restriction fragment length polymorphism (RFLP) in CICN4, between the loci for Xlinked ocular alblism (OA1) and microphthalmia with linear skin defects syndrome (MLS). Hum Genet 95: 594-595

Shastry BS (1993) Recent developments in certain X-linked genetic eye disorders. Biochim Biophys Acta 1182: 119-127

Stratton RF, Walter CA, Paulgar BR, Price ME, Moore CM (1998) Second 46,XX male with MLS stndrome. Am J Med Genet 76: 37-41

Temple IK, Hurst JA, Hing S, Butler L, Baraitser M (1990) De novo deletion of Xp22.2-pter in a female with linear skin lesions of the face and neck, microphthalmia, and anterior chamber eye anomalies. J Med Genet 27: 56-58

Temple IK, Al-Gazali LI (1995) Microphthalmia with linear skin defects and Xp22 deletions (MLS) syndrome. In Congenital malformation syndromes. Chapman \& Hall, London

Thies U, Rao VVNG, Engel W, Schmidtke J (1991) Physical mapping of two Xp markers DXS16 and DXS143. Hum Genet 86: 418420

Wapenaar MC, Bassi MT, Schaefer L, Grillo A, Ferrero GB, Chinault AC, Ballabio A, Zoghbi HY (1993) The genes for X-linked ocular albinism (OA1) and microphthalmia with linear skin defects (MLS): Cloning and characterization of critical regions. Hum Mol Genet 2: 947-952

Wettke-Schafer R, Kantner G (1983) X-linked dominant inherited diseases with lethality in hemizygous males. Hum Genet 64: 1-23 